\section{Effects of Early Defoliation on Yield, Fruit Composition, and Harvest Season Cluster Rot Complex of Grapevines}

\author{
Paolo Sabbatini ${ }^{1}$ and G. Stanley Howell \\ Department of Horticulture, Michigan State University, East Lansing, MI \\ 48864
}

Additional key words. Vitis vinifera, French-American hybrids, Botrytis cinerea, source-sink, fruit-set

\begin{abstract}
Viticulture in Michigan is limited by a cool and humid climate and as a result, there is a problem of harvest season cluster rot, especially in cultivars with compact cluster morphology. Economically important wine grape varieties in eastern North America possess varying susceptibility to harvest season cluster rot. Some important cultivars that are susceptible are Pinot gris, Pinot noir, Riesling (Vitis vinifera $\mathbf{L}$.) as well as Seyval and Vignoles (French-American hybrids or interspecific hybrid cultivars). A common characteristic of these cultivars is the compactness of the berries held on the cluster rachis. The aim of this work was to determine whether a quantified amount of leaf removal or a temporary reduction in carbon assimilation at the beginning of bloom would reduce fruit set and cluster compactness. Vines subjected to removal of four or six basal leaves had an average fruit set reduction of $\approx 45 \%$ from a non-treated control. Cluster weight and berries per cluster were similarly reduced with a greater effect on the basal than the apical cluster of the shoot. Reduced fruit set was associated with a reduction in cluster compactness and harvest season rot. This was also reflected in yield and basic fruit chemistry parameters associated with the importance of basal leaves to the developing cluster. Multiple applications of stylet oil at different time intervals resulted in significant reduction in net photosynthesis $\left(P_{n}\right)$. A single application had no significant impact on $P_{n}$, whereas multiple applications reduced leaf assimilation rates. However, this reduction in $\mathbf{P}_{\mathbf{n}}$ did not reduce fruit set or improve cluster compactness. There was a strong negative effect of early leaf removal in Year 1 on vine performance in Year 2; this carryover effect increased shootless nodes per vine, reduced the number of clusters per shoot and per vine, and dramatically reduced fruit set and consequently yield per vine.
\end{abstract}

Leaf removal in the fruiting zone is a classical vineyard management practice in applied during the summer, from fruit set to veraison (Reynolds et al., 1996). It is a pivotal operation on high-density canopies to improve clusters' microclimate (e.g., light exposure and air circulation) that reduces conditions favorable to bunch rot complex diseases (Percival et al., 1994; Reynolds et al., 1986, 1996; Zoecklein et al., 1992) while improving fruit quality (Smart et al., 1990), in particular berry pigmentation (Bureau et al., 2000; Kliewer and Antcliff, 1970; Lakso and Kliewer, 1975). However, leaf removal can also affect fruit

Received for publication 26 July 2010. Accepted for publication 27 Sept. 2010.

This research was supported by USDA Viticulture Consortium East, Michigan Agricultural Experiment Station, and the Southwest Michigan Research and Extension Center.

We appreciate the assistance of J. Treloar and L. Clearwater in collecting data, of D. Francis for his help in vineyard maintenance, of J.A. Wolpert, C. Intrieri for extensive discussions and of M.J. Bukovac, and E. Hanson for critical reading of an earlier version of the article.

${ }^{1}$ To whom reprint requests should be addressed; e-mail sabbatin@msu.edu.

eaf removal from the lower quarter of the canopy during the lag phase of berry growth resulted in a significant reduction in wholevine photosynthesis and demonstrated that the lower portion of the canopy (removed with leaf removal) contributed more than the upper portion to the whole-vine carbon budget. Moreover, the effects of leaf removal on yield vary depending on timing and severity. Because it is well known that carbohydrate supply at anthesis is a primary determinant of fruit set (Caspari and Lang, 1996; Vasconcelos et al., 2009), leaf removal within 4 weeks from anthesis generally reduces yield, cluster compactness, and total amount of sugar per berry (Kliewer and Antcliff, 1970). However, if leaves are removed later in the season (preor post-veraison) or at reduced level (severity), yield is not significantly affected and occasionally increases compared with the nondefoliated controls (Zoecklein et al., 1992).

Grape growing in the Great Lakes Viticultural Region is challenged by several environmental limits, primarily 1) spring frost and winter injury; 2) short and variable growing seasons; and 3) low heat accumulation (Howell, 2000, 2001; Howell and Sabbatini, 2008). Under these conditions, it is difficult to achieve maximum fruit maturity and crop control is a priority to assure high-quality wines (Intrieri et al., 2008; Smart et al., 1990). Cultivar cropping potential is determined by the genotypic bud fruitfulness and the traditional crop control strategy achieved by winter pruning, node count adjustment, and, for further fine-tuning, by shoot and cluster thinning. However, manual cluster thinning is time-consuming, expensive, and requires skilled labor. Manual defoliation at anthesis has been reported to reduce fruit set and berry size, leading to looser clusters with improved fruit composition (Intrieri et al., 2008; Poni et al., 2005, 2006, 2009; Sabbatini et al., 2010; Tardaguila et al., 2010). Intrieri et al. (2008) showed that both pre- and post-bloom hand and mechanical defoliation limited yield by reducing the number of berries per cluster of the heavy, densely compacted, high-cropping cultivar, Sangiovese (Vitis vinifera L.). Cluster weight was reduced, whereas most soluble solids (Brix) and total anthocyanins were increased. These data indicated that early mechanical defoliation is a viable crop adjustment tool and delivers most of the advantages of hand leaf removal for the productive and fertile red cultivar (Sangiovese) in a Mediterranean growing area.

Vine growth is functionally associated with the balance between the sink activity of vegetative and reproductive organs. Based on the relationship between carbohydrate availability near anthesis and final yield (Poni et al., 2009; Vasconcelos et al., 2009), the hypotheses of our study were 1) early leaf removal (at trace bloom) influences vine performance (yield, fruit composition, and quality in the initial year and vine productivity in the subsequent year); and 2) non-destructive, short-term photosynthesis reduction during trace bloom will influence vine performance in a manner similar to leaf removal.

\section{Materials and Methods}

Plant material and vineyard sites. The experiments were conducted at the Horticulture Teaching Research Center (HTRC in East Lansing; lat. $42.43^{\circ} \mathrm{N}$, long. $84.24^{\circ} \mathrm{W}$ ) and at the Southwest Michigan Research and Extension Center (SWMREC in Benton Harbor; lat. $40.09^{\circ} \mathrm{N}$, long. $86.36^{\circ} \mathrm{W}$ ) of Michigan State University. Michigan's climate is characterized by a short growing season (150 to $175 \mathrm{~d}$ ) with cool-climate conditions ( $1200 \pm$ 300 growing degree-days, base $10^{\circ} \mathrm{C}$ ). Yield and quality are often limited by several factors, namely spring freeze $(50 \%$ chance of spring frost as late as 15 May), early fall frost, high humidity, and rainfall during the harvest season (Howell and Sabbatini, 2008).

Own-rooted 'Vignoles' vines were grown at the HTRC on a Coupee clay loam (U.S. Department of Agriculture, Soil Conservation Service, 1957). Vines planted in 1975, spaced $2.5 \mathrm{~m}$ in rows, $3.0 \mathrm{~m}$ between rows, and trained to a Hudson River Umbrella (bilateral cordon 
at the top wire of $1.8 \mathrm{~m}$ ) were selected for uniformity. Production in this system comes from eight-node canes and two-node renewal spurs, spaced at $20 \mathrm{~cm}$ along the cordon, with canes and spurs alternated, leaving $\approx 60$ nodes per vine retained at pruning. 'Pinot noir' and 'Pinot gris' vines, on 3309 C rootstock, planted in 1987 in a Spinks loamy fine soil (U.S. Department of Agriculture, Soil Conservation Service, 1957) and trained to a low-head vertical shoot positioning system with a spacing of $1.8 \mathrm{~m}$ in rows and $3.0 \mathrm{~m}$ between rows, were selected at the SWMREC. Vines were cane pruned and trained to 50 nodes (four canes with 12 to 14 nodes for fruiting and three to four two-node renewal spurs at the head) on a permanent wire at $1.0 \mathrm{~m}$ from the ground and a double set of catch wires at 1.4 and $2.0 \mathrm{~m}$ from the ground, respectively. The frequency of cold damage to buds required implementation of the spare-parts pruning technique developed by Pool and Howard (1984). Recommended crop protection practices were followed and the pest management program was based on scouting, experience, and weather conditions. A combination of fungicides and insecticides used for control was rotated to avoid resistance. Fertilizing consisted of annual application of post-bloom nitrogen at $30 \mathrm{~kg} \cdot \mathrm{ha}^{-1}$ in the form of calcium nitrate or ammonium nitrate. No irrigation was provided and standard summer vine canopy management practices were used. Temperature data were recorded during the experiment by an automated weather station from the Michigan Automated Weather Network located on the sites $200 \mathrm{~m}$ from the experimental vineyards.

Treatments and experimental design. A randomized complete block design, using mature 'Vignoles' vines, was used with four blocks per treatment and six vines per block. During Year 1, two manual leaf removal treatments were compared with a non-defoliated control (Expt. 1). Treatments were applied during the phenological phase 19 (trace bloom) described by Eichhorn and Lorenz (1977). Treatments consisted of zero (d0: control), four (d4), and six (d6) basal leaves removed to all shoots of the vine. Before the leaf removal treatment, three modal shoots per vine with two clusters per shoot (apical and basal position) were tagged for seasonal detailed measurements (fruit set and cluster compactness). Number of florets was counted on 150 clusters per treatment collected in vines similarly treated but not used in the experiment. Calculation of percentage of fruit set was performed as described by Buttrose (1970) and Dunn and Martin (2007). During Year 2, vines used for the Year 1 leaf removal experiment were grown with no leaf removal, following standard commercial practices, to assess any carryover response of bud performance, shoot fruitfulness, and vine productivity.

In a second year of Expt. 1, six basal leaves of 'Vignoles' vines were sprayed, until fully wetted, with a mineral oil (JMS stylet-oil; Flower Farms Inc., Vero Beach, FL) with a concentration of $2 \%\left(75 \mathrm{~L} \cdot \mathrm{ha}^{-1}\right)$. Foliar treatments were made as a single application at trace bloom and multiple application at trace bloom and $3 \mathrm{~d}$ later and at trace bloom and 3 and $5 \mathrm{~d}$ later (Expt. 2). Stylet oil was chosen based on the work of Finger et al. (2002) showing a short-term reduction in photosynthesis of this compound when applied on vines. Leaf assimilation $\left(\mathrm{P}_{\mathrm{n}}\right)$ was measured in the morning (1000 $\mathrm{HR}$ to $1200 \mathrm{HR}$ ) before the defoliation and for $10 \mathrm{~d}$ after the spray treatment on three tagged shoots per vine at Nodes 5, 6, and 7. Single leaf gas exchange parameters [carbon dioxide assimilation rate $\left(\mathrm{P}_{\mathrm{n}}\right)$, stomatal conductance, and internal $\mathrm{CO}_{2}$ concentration] were measured with a CIRAS2 portable open system gas analyzer (PP System, Hitchin Herts, U.K.) operated at 0.2 $\mathrm{L} \cdot \mathrm{min}^{-1}$ flow rate and ambient $\mathrm{CO}_{2}$ of $\approx 34 \mathrm{~Pa}$. Leaf photosynthesis was measured using sunlight as the light source at a photosynthetic photon flux density always higher than $900 \mu \mathrm{mol} \cdot \mathrm{m}^{-2} \cdot \mathrm{s}^{-1}$.

A similar experiment using 'Pinot noir' and 'Pinot gris' was performed at the SWMREC. A randomized complete block design was used with four blocks per treatment and three vines per block. Two manual leaf removal treatments were compared with a nondefoliated control. Treatments were applied during the phenological phase 19 (trace bloom) described by Eichhorn and Lorenz (1977) and they consisted of zero (d0: control), four (d4), and six (d6) basal leaves removed from all shoots of the vine.

Data collection. Yield per vine was measured at harvest and the number of clusters per vine counted. Samples of 250 random berries per vine were collected and weighed at harvest for each treatment and mean berry weight per vine determined. The yield and berry weight values were used to estimate cluster weight and berries per cluster, respectively. Chemical composition of fruit was analyzed using the 250-count berry sample per vine collected on the day of harvest and frozen for later analysis (Iland et al., 2004). Before analysis, berries were thawed at $24{ }^{\circ} \mathrm{C}$ for $24 \mathrm{~h}$. Grape juice soluble solids were analyzed using an Atago refractometer (Kirkland, WA), and $\mathrm{pH}$ was measured using a 370 Thermo Orion (Beverly, MA) $\mathrm{pH}$ meter. An automatic titrator, coupled to an autosampler and control unit (Titroline 96, Schott, Germany), was used to determine titratable acidity.

Harvest cluster rot was determined as incidence (percentage of infected clusters per vine) and as severity (percentage of infected berries per cluster). Counts of shootless nodes per vine and measurements of shoot fruitfulness were made on the vines the next year to evaluate potential carryover effects on vine productivity. Cluster compactness (CI) was indexed as ratio between the number of berries per cluster and rachis length $(\mathrm{cm})$.

Basic statistics, analysis of variance (ANOVA), and correlation analysis were performed using SAS (SAS Version 9.1.3; SAS Institute Inc., Cary, NC) and Sigma Plot (Version 10; SPSS, Chicago, IL). Results were tested for homogeneity of variance and subjected to ANOVA.

\section{Results and Discussion}

Leaf removal treatments ( $\mathrm{d} 4$ and $\mathrm{d} 6)$ in Year- 1 reduced fruit set in 'Vignoles' (Table 1) by $25 \%$ and $42 \%$, respectively, relative to

Table 1. Effect of early leaf removal treatments on number of clusters per vine, fruit set, and basic fruit chemistry in 'Vignoles'.

\begin{tabular}{|c|c|c|c|c|c|}
\hline \multirow[b]{2}{*}{ Parameter $^{\mathrm{Z}}$} & \multicolumn{3}{|c|}{ Treatment $^{\mathrm{y}}$} & \multicolumn{2}{|c|}{$\mathrm{d} 0=100^{\mathrm{x}}$} \\
\hline & d0 & $\mathrm{d} 4$ & d6 & $\mathrm{d} 4$ & d6 \\
\hline Yield/vine (kg) & $18.7 \mathrm{a}$ & $15.4 \mathrm{~b}$ & $7.1 \mathrm{c}$ & 82 & 38 \\
\hline Cluster/vine & $231.0 \mathrm{a}$ & $202.0 \mathrm{~b}$ & $143.0 \mathrm{c}$ & 87 & 62 \\
\hline \multirow[t]{2}{*}{ Cluster/shoot } & $2.0 \mathrm{a}$ & $2.0 \mathrm{a}$ & $1.9 \mathrm{a}$ & 100 & 95 \\
\hline & & ruit set $(\%$ & & & \\
\hline Shoot & $60.0 \mathrm{a}$ & $45.0 \mathrm{~b}$ & $35.0 \mathrm{c}$ & 75 & 58 \\
\hline Basal cluster & $54.0 \mathrm{a}$ & $42.0 \mathrm{~b}$ & $27.0 \mathrm{c}$ & 78 & 50 \\
\hline \multirow[t]{2}{*}{ Apical cluster } & $64.0 \mathrm{a}$ & $49.0 \mathrm{~b}$ & $43.0 \mathrm{~b}$ & 77 & 67 \\
\hline & & $C I^{w}$ & & & \\
\hline Shoot & $5.5 \mathrm{a}$ & $5.0 \mathrm{a}$ & $3.0 \mathrm{~b}$ & 91 & 55 \\
\hline Basal cluster & $5.0 \mathrm{a}$ & $4.0 \mathrm{~b}$ & $3.0 \mathrm{c}$ & 80 & 60 \\
\hline \multirow[t]{2}{*}{ Apical cluster } & $6.0 \mathrm{a}$ & $6.0 \mathrm{a}$ & $3.4 \mathrm{~b}$ & 100 & 57 \\
\hline & & Cluster & & & \\
\hline Berry weight (g) & $1.4 \mathrm{a}$ & $1.4 \mathrm{a}$ & $1.4 \mathrm{a}$ & 100 & 100 \\
\hline Berries/cluster & $56.0 \mathrm{a}$ & $51.0 \mathrm{a}$ & $36.0 \mathrm{~b}$ & 93 & 64 \\
\hline Cluster weight (g) & $81.0 \mathrm{a}$ & $76.0 \mathrm{a}$ & $49.8 \mathrm{~b}$ & 94 & 61 \\
\hline${ }^{\circ} \operatorname{Brix}(\%)$ & $19.6 \mathrm{a}$ & $20.6 \mathrm{a}$ & $22.2 \mathrm{~b}$ & 105 & 113 \\
\hline $\mathrm{pH}$ & $3.10 \mathrm{a}$ & $3.13 \mathrm{a}$ & $3.20 \mathrm{a}$ & 101 & 103 \\
\hline \multirow[t]{2}{*}{ Titratable acidity $\left(\mathrm{g} \cdot \mathrm{L}^{-1}\right)$} & $13.0 \mathrm{a}$ & $12.7 \mathrm{a}$ & $13.5 \mathrm{a}$ & 98 & 104 \\
\hline & & Harvest ro & & & \\
\hline Incidence $^{v}$ & $24 \mathrm{a}$ & $16 \mathrm{~b}$ & $2 \mathrm{c}$ & 67 & 8 \\
\hline$\underline{\text { Severity }}^{\mathrm{u}}$ & $20 \mathrm{a}$ & $12 \mathrm{~b}$ & $0.5 \mathrm{c}$ & 60 & 3 \\
\hline
\end{tabular}

${ }^{\mathrm{z}}$ Means in a row followed by the same letters are not significantly different at $P=0.05$ by the Tukey's honestly significant difference test.

${ }^{\mathrm{y}} \mathrm{d} 0, \mathrm{~d} 4$, and $\mathrm{d} 6=0,4$, and 6 basal leaves removed (defoliation) during trace bloom, respectively. ${ }^{\mathrm{x}}$ Variation $(\%)$ of treatments $\mathrm{d} 4$ and $\mathrm{d} 6$ from control $(\mathrm{d} 0=100)$.

${ }^{\mathrm{w}} \mathrm{CI}=$ compactness index: ratio between number of berries per cluster and rachis length $(\mathrm{cm})$.

'Incidence: percentage of infected cluster per vine.

uSeverity: percentage of infected berries per cluster. 
the control. The effect was different between the apical and the basal clusters. In particular, removing six leaves (d6) resulted in a fruit set of $27 \%$ in the basal cluster of the shoot and by $43 \%$ in the apical cluster of the shoot. The reduction of fruit set in the apical cluster of d6 was similar to that of the basal cluster in the $\mathrm{d} 4$ treatment (Table 1). An increase in photosynthesis was observed in leaves of the d6 defoliated shoot $(\approx+20 \%$ to $35 \%$ relatively to the control; data not shown). This increase in photosynthesis may be related to capacity of the leaves to temporarily compensate for a reduction of leaf area (Candolfi-Vasconcelos and Koblet, 1991; Petrie et al., 2003).

The reduction in fruit set resulted in fewer berries per cluster and consequently a lower cluster weight ( $-49 \%$ in d6 from the control). However, the reduction in berries per cluster was not accompanied by an increase in berry weight (Table 1). Berry weight was identical for each level of defoliation and no compensation effect was observed. Differences in fruit set influenced cluster compactness; CI was reduced by $9 \%$ and $45 \%$ in $\mathrm{d} 4$ and $\mathrm{d} 6$, respectively. The reduction in cluster weight and number of clusters per vine resulted in a reduced yield per vine of $16 \%$ and $72 \%$ in $\mathrm{d} 4$ and d6, respectively. Soluble solids (Brix) were increased by 1.0 and $2.6^{\circ}$ Brix in $\mathrm{d} 4$ and $\mathrm{d} 6$, respectively, but $\mathrm{pH}$ and titratable acidity were unaffected (Table 1).

In the second year of Expt. 1, the vines were managed according to recommended standard practices (Table 2) and no leaf removal was performed. There was a significant carryover effect of Year 1 treatments in Year 2. The number of shootless nodes per vine was not impacted by the leaf removal treatments applied the previous year. However, the shootless node percentage differed based on node position on the cane. For node position 1-4, there was a higher shootless node percentage as compared with node position 4-7 in all the treatments. When comparing treatment effect of node position 1-4, defoliation significantly increased shootless node percentage, but the defoliation treatments were not different. Node position 4-7 by contrast showed a progressive increased in shootless percentage as the number of leaves removed increased. There was a significant reduction in number of clusters per shoot resulting from the removal of six leaves per shoot. This was true regardless of node position or on a per-vine basis. Similarly, florets per cluster on apical, basal, and per-shoot bases were reduced by the $\mathrm{d} 6$ treatment (Table 2). Comparatively, percentage of fruit set was dramatically reduced in the vines of treatment $\mathrm{d} 6$ the prior year (only $4 \%$ of the control) in the basal cluster of the shoot. Consequently, these factors combined influenced yield per vine very significantly. Yield per vine was reduced by $55 \%$ and $83 \%$, from the control, in treatments $\mathrm{d} 4$ and $\mathrm{d} 6$, respectively.

The extreme reduction of bud fertility in Year 2 caused by the early manual defoliation (at trace bloom in Year 1) suggested the potential value of a short-term photosynthesis inhibitor. A temporary reduction of leaf assimilation could have the potential of mimicking the effect of leaf removal without eliminating the leaf area around the cluster that controls bud initiation and differentiation for the next season's crop (Vasconcelos et al., 2009). Photosynthesis (Fig. 1) was not reduced by one application (A) but was reduced by two and three sprays (B and $\mathrm{C}$ ) at 2-d intervals. Two sprays of stylet oil (B) reduced assimilation by $30 \%$ from the control (d0) for $\approx 1 \mathrm{~d}$ and for $\approx 3 \mathrm{~d}$ with three applications (C). After $7 \mathrm{~d}$, all the treatments showed the same levels of assimilation (Fig. 1). During the experiment, $\mathrm{P}_{\mathrm{n}}$ of control vines $(\mathrm{d} 0)$ was $12.4 \pm 1.9 \mathrm{sD} \mu \mathrm{mol} \mathrm{CO} 2 / \mathrm{m}^{-2} \cdot \mathrm{s}^{-1}$. Results from this Year 2 experiment confirmed the previous year's effect of the leaf removal (d4) on all the important vine and fruit chemistry parameters collected (Table 3), and in partic- ular on CI, which was reduced by $\approx 20 \%$ from the untreated control. Conversely, the foliar treatments (A, B, and $\mathrm{C})$ reduced the photosynthetic activity of the leaves without affecting any of the parameters measured (Table 3) with a slight tendency toward reducing CI.

The study was also carried out on vinifera cultivars (Pinot noir and Pinot gris) during Year 2 and results are presented in Table 4. Leaf removal at trace bloom with two intensities (d4 and d6) did not significantly affect any of the parameters measured, revealing only a slight decrease in cluster weight for 'Pinot noir'. However, a slight reduction of fruit set in 'Pinot gris' was recorded with a reduction in bunch rot without changing other morphological and chemical characteristics of the clusters. Our finding is dissimilar with previous research reports (Intrieri et al., 2008; Poni et al., 2005;

Table 2. Carryover effects of defoliation treatments in Year 1 on bud fertility and yield of 'Vignoles' vines in Year 2.

\begin{tabular}{|c|c|c|c|c|c|}
\hline \multirow{2}{*}{ Parameter ${ }^{\mathrm{x}}$} & \multicolumn{3}{|c|}{ Treatment $^{y}$} & \multicolumn{2}{|c|}{$\mathrm{d} 0=100^{\mathrm{w}}$} \\
\hline & d0 & $\mathrm{d} 4$ & d6 & $\mathrm{d} 4$ & $\mathrm{~d} 6$ \\
\hline \multicolumn{6}{|c|}{ Shootless nodes (\%) } \\
\hline Nodes $1-4$ & $20 \mathrm{~b}$ & $26 \mathrm{a}$ & $27 \mathrm{a}$ & 130 & 135 \\
\hline Nodes 4-7 & $17 \mathrm{c}$ & $20 \mathrm{~b}$ & $24 \mathrm{a}$ & 118 & 141 \\
\hline Per vine & $29 \mathrm{a}$ & $28 \mathrm{a}$ & $33 \mathrm{a}$ & 97 & 114 \\
\hline \multicolumn{6}{|c|}{ Cluster/shoot } \\
\hline Nodes $1-4$ & $2.0 \mathrm{a}$ & $1.7 \mathrm{a}$ & $1.1 \mathrm{~b}$ & 85 & 55 \\
\hline Nodes 4-7 & $2.0 \mathrm{a}$ & $1.9 \mathrm{a}$ & $1.7 \mathrm{~b}$ & 95 & 85 \\
\hline Per vine & $2.0 \mathrm{a}$ & $1.8 \mathrm{a}$ & $1.4 \mathrm{~b}$ & 90 & 70 \\
\hline \multicolumn{6}{|c|}{ Florets } \\
\hline Apical cluster & $273 \mathrm{a}$ & $271 \mathrm{a}$ & $248 \mathrm{~b}$ & 99 & 91 \\
\hline Basal cluster & $188 \mathrm{a}$ & $184 \mathrm{a}$ & $173 \mathrm{a}$ & 98 & 92 \\
\hline Per shoot & $461 \mathrm{a}$ & $454 \mathrm{a}$ & $421 \mathrm{~b}$ & 98 & 91 \\
\hline \multicolumn{6}{|c|}{ Fruit set $(\%)^{z}$} \\
\hline Apical cluster & 100 & 84 & 20 & & \\
\hline Basal cluster & 100 & 68 & 4 & & \\
\hline Per shoot & 100 & 76 & 12 & & \\
\hline \multicolumn{6}{|c|}{ Yield (kg) } \\
\hline Yield/vine & $14.4 \mathrm{a}$ & $6.5 \mathrm{~b}$ & $2.4 \mathrm{c}$ & 45 & 17 \\
\hline
\end{tabular}

${ }^{\mathrm{z}}$ Fruit set calculated as percentage variation from control (d0).

$\mathrm{y} 0, \mathrm{~d} 4$, and $\mathrm{d} 6=0,4$, and 6 basal leaves removed (defoliation) during trace bloom, respectively.

${ }^{x}$ Means in a row followed by the same letters are not significantly different at $P=0.05$ by the Tukey's honestly significant difference test.

${ }^{w}$ Variation $(\%)$ of treatments $\mathrm{d} 4$ and $\mathrm{d} 6$ from control $(\mathrm{d} 0=100)$.

Table 3. Effect of early leaf removal (4 basal leaves: 4d) and multiple applications (A, B, C) of JMS stylet oil $\left(2 \%, 75 \mathrm{~L} \cdot \mathrm{ha}^{-1}\right)$ at bloom, 3 and $5 \mathrm{~d}$, on yield and basic fruit chemistry in cv. Vignoles.

\begin{tabular}{lrrrrr}
\hline & \multicolumn{5}{c}{ Treatment $^{y}$} \\
\cline { 2 - 6 } Parameter $^{\mathrm{y}}$ & $\mathrm{d} 0$ & $\mathrm{~d} 4$ & $\mathrm{~A}$ & $\mathrm{~B}$ & $\mathrm{C}$ \\
\hline${\text { Vine size }(\mathrm{kg})^{\mathrm{w}}}^{\text {Nodes retained }}$ & $1.1 \mathrm{a}$ & $1.2 \mathrm{a}$ & $1.1 \mathrm{a}$ & $1.2 \mathrm{a}$ & $0.92 \mathrm{a}$ \\
Yield/vine $(\mathrm{kg})$ & $64 \mathrm{a}$ & $64 \mathrm{a}$ & $64 \mathrm{a}$ & $64 \mathrm{a}$ & $64 \mathrm{a}$ \\
Cluster/vine & $4.9 \mathrm{a}$ & $2.8 \mathrm{~b}$ & $5.5 \mathrm{a}$ & $5.8 \mathrm{a}$ & $3.8 \mathrm{a}$ \\
Cluster weight $(\mathrm{g})$ & $50 \mathrm{a}$ & $43 \mathrm{a}$ & $38 \mathrm{a}$ & $47 \mathrm{a}$ & $36 \mathrm{a}$ \\
Berry weight $(\mathrm{g})$ & $128 \mathrm{a}$ & $78 \mathrm{~b}$ & $121 \mathrm{ab}$ & $134 \mathrm{a}$ & $121 \mathrm{ab}$ \\
Berries/cluster & $1.5 \mathrm{a}$ & $1.4 \mathrm{a}$ & $1.4 \mathrm{a}$ & $1.6 \mathrm{a}$ & $1.5 \mathrm{a}$ \\
Cluster/shoot & $86 \mathrm{a}$ & $56 \mathrm{~b}$ & $85 \mathrm{a}$ & $84 \mathrm{a}$ & $80 \mathrm{a}$ \\
Florets/cluster & $0.8 \mathrm{a}$ & $0.7 \mathrm{a}$ & $0.6 \mathrm{a}$ & $0.7 \mathrm{a}$ & $0.6 \mathrm{a}$ \\
CI & $243 \mathrm{a}$ & $277 \mathrm{a}$ & $248 \mathrm{a}$ & $221 \mathrm{a}$ & $251 \mathrm{a}$ \\
${ }^{\circ}$ Brix (\%) & $6.9 \mathrm{a}$ & $5.6 \mathrm{~b}$ & $8.0 \mathrm{a}$ & $7.6 \mathrm{a}$ & $7.3 \mathrm{a}$ \\
pH & $24.6 \mathrm{a}$ & $24.7 \mathrm{a}$ & $24.6 \mathrm{a}$ & $24.8 \mathrm{a}$ & $24.8 \mathrm{a}$ \\
Titratable acidity $\left(\mathrm{g} \cdot \mathrm{L}^{-1}\right)$ & $3.38 \mathrm{a}$ & $3.36 \mathrm{a}$ & $3.36 \mathrm{a}$ & $3.36 \mathrm{a}$ & $3.40 \mathrm{a}$ \\
\hline
\end{tabular}

${ }^{\mathrm{z}} \mathrm{CI}=$ compactness index: ratio between number of berries per cluster and rachis length $(\mathrm{cm})$.

${ }^{\mathrm{y}} \mathrm{d} 0, \mathrm{~d} 4=0$ and 4 basal leaves removed (defoliation) during trace bloom, respectively. A, B, C = multiple foliar applications of JMS stylet oil $\left(2 \%, 75 \mathrm{~L} \cdot \mathrm{ha}^{-1}\right)$, at trace bloom (A) and after 3 (B) and 5 (C) d.

${ }^{x}$ Means in a row followed by the same letters are not significantly different at $P=0.05$ by the Tukey's honestly significant difference test.

${ }^{\text {w}}$ Vine size indexed as pruning weight $(\mathrm{kg})$. 


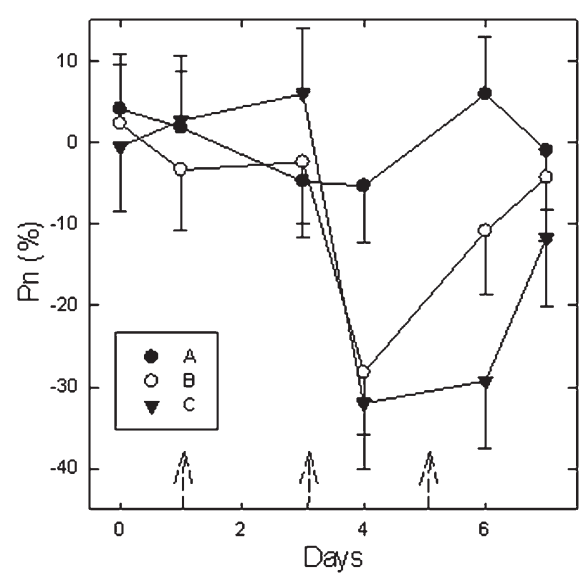

Fig 1. Effect of multiple foliar applications of JMS stylet oil $\left(2 \%, 75 \mathrm{~L} \cdot \mathrm{ha}^{-1}\right)$ to basal nodes 1 to 6 on non-defoliated 'Vignoles grapevines', at trace bloom (A, Day 1) and at trace bloom and after 3 (B, Days 1 and 3) and at trace bloom after 3 and 5 days (C, Days 1, 3, and 5) on leaf photosynthesis $\left(\mu \mathrm{mol} \mathrm{CO} 2 / \mathrm{m}^{-2} \cdot \mathrm{s}^{-1}\right)$ expressed as variation (\%) from unsprayed control. Photosynthesis measurements were taken on leaf node position five from the base of the shoot. Bars represent SD. Arrows indicate days of application.

Tardaguila et al., 2010). However, the use of small-clustered varieties in our study in contrast with very large-clustered varieties ('Sangiovese', 'Barbera', 'Graciano', and 'Carignan', with 750 to 850 florets per cluster) used in other viticultural region of the world (Intrieri et al., 2008; Tardaguila et al., 2010) could be the explanation of this different results. 'Vignoles', 'Pinot noir', and 'Pinot gris' tend to have less flowers per cluster (150 to 200) and the tendency to set more.

Averaging the data collected for 'Pinot gris' and 'Pinot noir' and comparing with the average of all the interspecific hybrid cultivars' data [Vignoles (Seyval, Delaware, and Marechal Foch data not shown)] collected in this study, a correlation can be shown between defoliation intensity (number of leaves removed at trace bloom) and cluster weight expressed as percentage reduction from the control treatment (Fig. 2). Interspecific hybrid cultivars were more responsive to leaf removal than vinifera cultivars, demonstrating a reduction of cluster weight up to $90 \%$ with eight leaves removed in Delaware (data not shown). Vinifera cultivars tend to have less reduction in cluster weight by the leaf removal treatment at trace bloom demonstrated by a lesser effect ( $-20 \%$ from the control) with six leaves removed. We speculate that this is a response to lower shoot vigor of the vinifera cultivars at the time of leaf removal compared with the interspecific hybrid cultivars and the more vigorously growing shoots during fruit set could more effectively compete with the clusters at anthesis for available carbohydrates (Vasconcelos et al., 2009).

\section{Conclusion}

Fruit set reduction resulting from early leaf removal, in all the cultivars used in this

Table 4. Effect of early leaf removal treatments on number of clusters per vine, fruit set, and basic fruit chemistry in 'Pinot gris' and 'Pinot noir' vines, Benton Harbor, MI.

\begin{tabular}{|c|c|c|c|c|c|c|}
\hline \multirow[b]{3}{*}{ Parameter $^{\mathrm{x}}$} & \multicolumn{6}{|c|}{ Treatment $^{\mathrm{y}}$} \\
\hline & \multicolumn{3}{|c|}{ Pinot gris } & \multicolumn{3}{|c|}{ Pinot noir } \\
\hline & $\mathrm{d} 0$ & $\mathrm{~d} 4$ & d6 & $\mathrm{d} 0$ & $\mathrm{~d} 4$ & d6 \\
\hline Vine size $(\mathrm{kg})^{\mathrm{w}}$ & $0.8 \mathrm{a}$ & $0.91 \mathrm{a}$ & $0.91 \mathrm{a}$ & $2.0 \mathrm{a}$ & $1.9 \mathrm{a}$ & $2.2 \mathrm{a}$ \\
\hline Shoot/vine & $45 \mathrm{a}$ & $45 \mathrm{a}$ & $45 \mathrm{a}$ & $45 \mathrm{a}$ & $45 \mathrm{a}$ & $45 \mathrm{a}$ \\
\hline Yield/vine (kg) & $6.97 \mathrm{a}$ & $5.53 \mathrm{a}$ & $6.23 \mathrm{a}$ & $5.0 \mathrm{a}$ & $3.2 \mathrm{a}$ & $4.3 \mathrm{a}$ \\
\hline Cluster/vine & $68 \mathrm{a}$ & $65 \mathrm{a}$ & $72 \mathrm{a}$ & $63 \mathrm{a}$ & $49 \mathrm{a}$ & $53 \mathrm{a}$ \\
\hline Cluster weight (g) & $115 \mathrm{a}$ & $111 \mathrm{a}$ & $99 \mathrm{a}$ & $117 \mathrm{a}$ & $101 \mathrm{~b}$ & $106 a b$ \\
\hline Berry weight (g) & $1.5 \mathrm{a}$ & $1.5 \mathrm{a}$ & $1.4 \mathrm{a}$ & $1.4 \mathrm{a}$ & $1.4 \mathrm{a}$ & $1.4 \mathrm{a}$ \\
\hline Berries/cluster & $79 \mathrm{a}$ & $75 \mathrm{a}$ & $70 \mathrm{~b}$ & $84 \mathrm{a}$ & $77 \mathrm{a}$ & $80 \mathrm{a}$ \\
\hline Cluster/shoot & $1.5 \mathrm{a}$ & $1.4 \mathrm{a}$ & $1.6 \mathrm{a}$ & $1.4 \mathrm{a}$ & $1.1 \mathrm{a}$ & $1.2 \mathrm{a}$ \\
\hline Florets/cluster & $112 \mathrm{a}$ & $138 \mathrm{a}$ & $161 \mathrm{a}$ & $196 \mathrm{a}$ & $189 \mathrm{a}$ & $199 \mathrm{a}$ \\
\hline Fruit set $(\%)$ & $59 \mathrm{a}$ & $47 \mathrm{ab}$ & $41 \mathrm{~b}$ & $47 \mathrm{a}$ & $45 \mathrm{a}$ & $47 \mathrm{a}$ \\
\hline $\mathrm{CI}^{\mathrm{z}}$ & $8.5 \mathrm{a}$ & $8.2 \mathrm{a}$ & $8.2 \mathrm{a}$ & $7.5 \mathrm{a}$ & $7.6 \mathrm{a}$ & $7.1 \mathrm{a}$ \\
\hline${ }^{\circ} \operatorname{Brix}(\%)$ & $21.6 \mathrm{a}$ & $21.7 \mathrm{a}$ & $21.8 \mathrm{a}$ & $22.7 \mathrm{a}$ & $23.3 \mathrm{a}$ & $23.2 \mathrm{a}$ \\
\hline $\mathrm{pH}$ & $3.75 \mathrm{a}$ & $3.81 \mathrm{a}$ & $3.81 \mathrm{a}$ & $3.77 \mathrm{a}$ & $3.84 \mathrm{a}$ & $3.87 \mathrm{a}$ \\
\hline Titratable acidity $\left(\mathrm{g} \cdot \mathrm{L}^{-1}\right)$ & $4.8 \mathrm{a}$ & $4.8 \mathrm{a}$ & $4.6 \mathrm{a}$ & $5.34 \mathrm{a}$ & $4.84 \mathrm{~b}$ & $4.79 \mathrm{~b}$ \\
\hline Bunch rot $(\%)$ & $3.5 \mathrm{a}$ & $3.0 \mathrm{a}$ & $1.2 \mathrm{~b}$ & $11.2 \mathrm{a}$ & $7.5 \mathrm{a}$ & $7.4 \mathrm{a}$ \\
\hline
\end{tabular}

${ }^{\mathrm{z}} \mathrm{CI}=$ compactness index: ratio between number of berries per cluster and rachis length $(\mathrm{cm})$.

${ }^{\mathrm{y}} \mathrm{d} 0, \mathrm{~d} 4$, and $\mathrm{d} 6=0,4$, and 6 basal leaves removed (defoliation) during trace bloom, respectively.

${ }^{\mathrm{x}} \mathrm{Means}$ in a row followed by the same letters are not significantly different at $P=0.05$.

${ }^{\mathrm{w}}$ Vine size indexed as pruning weight $(\mathrm{kg})$.

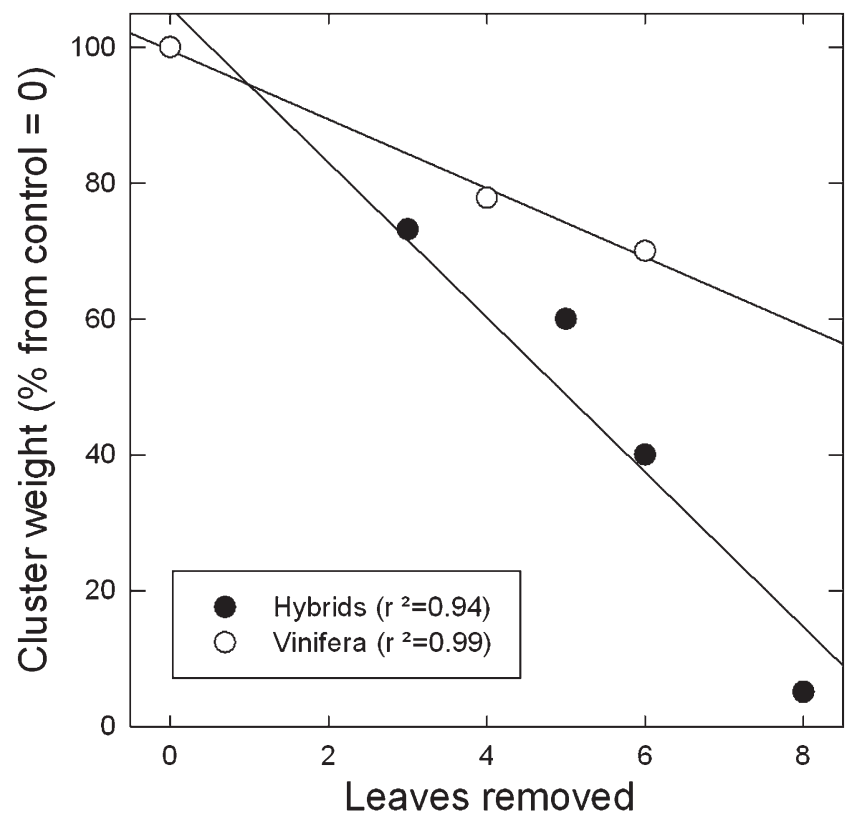

Fig 2. Correlation between defoliation intensity (number of leaves removed at trace bloom) and cluster weight expressed as percentage reduction from the control treatment shown as average effect on vinifera ('Pinot gris' and 'Pinot noir') and hybrid ('Vignoles', 'Seyval', 'Delaware', and 'Marechal Foch') cultivars. Data from 'Seyval', 'Delaware', and 'Marechal Foch' are unpublished.

study, except 'Pinot noir', confirmed the importance of carbohydrate supply during the fruit set period (Caspari and Lang, 1996; Caspari et al., 1998; Lebon et al., 2008; Vasconcelos et al., 2009). However, storage reserves could play a major role in this experiment, suggesting a differential ability of their use. Translocation of reserves could be different in the spring between cultivars used in this experiment, in particular during the transition phase of using stored starch and/ or newly produced photosynthetic carbohydrates (Lebon et al., 2008). In affected cultivars, cluster morphology (weight and number of berries) was modified by leaf removal treatments at trace bloom without inducing a compensation effect on the berry size.
Morphological and chemical characteristics of the clusters were positively impacted, especially cluster compactness, reduced by $\approx 15 \%$ and Brix increased by $\approx 10 \%$ across all the cultivars in relation to the non-defoliated control. Early leaf removal also reduced cluster rot of $\approx 34 \%$, reducing cluster compactness, a morphological characteristic of the cluster that is tightly related to bunch rot at harvest (Hed et al., 2009). Although application of stylet oil reduced $\mathrm{P}_{\mathrm{n}}$ by $30 \%$, this did not result in reduced fruit set or cluster compactness. However, the rate of application was low and was applied only to leaves 1 to 6 . Further evaluations involving both increased concentrations and whole vine applications should be considered. 
Defoliation in Year 1 increased shootless node percentage in Year 2, especially in d6 treatment. From our data, we cannot assess whether this is related to reduced bud cold hardiness or bud damage resulting from the leaf removal practice. However, the Year 1 treatment reduced number of clusters per shoot and the clusters produced fewer florets than the control. Year 1 early leaf removal severely reduced fruit set in Year 2. Unless these negative carryover responses can be ameliorated, this approach to reduce cluster compactness and cluster rot will not be acceptable. We speculate that this could be readily accommodated through retaining non-fruiting shoots at the head with all leaves retained that serve as canes to be retained for production in the next year.

\section{Literature Cited}

Bureau, S.M., R.L. Baumes, and A.J. Razungles. 2000. Effects of vine or bunch shading on the glycosylated flavor precursor in grapes of Vitis vinifera L. cv Syrah. J. Agr. Food Chem. 48: 1290-1297.

Buttrose, M.S. 1970. Fruitfulness in grapevines: The response of different cultivars to light, temperature and daylength. Vitis 9:121-125.

Candolfi-Vasconcelos, M.C. and W. Koblet. 1991. Influence of partial defoliation on gas exchange parameters and chlorophyll content of fieldgrown grapevines. Mechanism and limitations of the compensation capacity. Vitis 30:129-141.

Caspari, H.W. and A. Lang. 1996. Carbohydrate supply limits fruit-set in commercial Sauvignon Blanc grapevines. Proc. 4th International Cool Climate Viticulture Symposium. p. 9-13.

Caspari, H.W., A. Lang, and A.P. Alspach. 1998. Effect of girdling and leaf removal on fruit set and vegetative growth in grape. Amer. J. Enol. Viticult. 49:359-366.

Dunn, G.M. and S.R. Martin. 2007. A functional association in Vitis vinifera L. cv. Cabernet Sauvignon between the extent of primary branching and the number of flowers formed per inflorescence. Aust. J. Grape Wine Res. 13:95-100.

Eichhorn, K.W. and D.H. Lorenz. 1977. Phö enologische Entwicklungsstadie. Der rebe. Nachrichtenb. Deutsch Pflanzenschutzd (Braunschweig) 29: 119-120.

Finger, S.A., T.K. Wolf, and A.B. Baudoin. 2002. Effects of horticultural oils on the photosyn- thesis, fruit maturity, and crop yield of winegrapes. Amer. J. Enol. Viticult. 53:116-124.

Hed, B., H.K. Ngugi, and J.W. Travis. 2009. Relationship between cluster compactness and bunch rot in Vignoles grapes. Plant Dis. 93: $1195-1201$.

Howell, G.S. 2000. Grapevine cold hardiness: Mechanisms of cold acclimation, mid-winter hardiness maintenance, and spring deacclimation. Amer. J. Enol. Viticult. 51:35-48.

Howell, G.S. 2001. Sustainable grape productivity and the growth-yield relationship: A review. Amer. J. Enol. Viticult. 52:165-174.

Howell, G.S. and P. Sabbatini. 2008. Achieving vine balance with variable annual weather conditions. Proc. of the Midwest Grape and Wine Conference (MO). p. 93-103.

Iland, P., N. Bruer, G. Edwards, S. Weeks, and E. Wilkes. 2004. Chemical analysis of grapes and wine; techniques and concepts. Patrick Iland Wine Promotions Pty. Ltd., Adelaide, Australia.

Intrieri, C., I. Filippetti, G. Allegro, M. Centinari, and S. Poni. 2008. Early defoliation (hand vs mechanical for improved crop control and grape composition in Sangiovese (Vitis vinifera L.). Aust. J. Grape Wine Res. 14:25-32.

Kliewer, W.M. and A.J. Antcliff. 1970. Influence of defoliation, leaf darkening, and cluster shading on the growth and composition of sultana grapes. Amer. J. Enol. Viticult. 21:26-36.

Lakso, A.N. and W.M. Kliewer. 1975. The influence of temperature on malic acid metabolism in grape berries. Plant Physiol. 56:370-372.

Lebon, G., G. Wojanarowiez, B. Holzapfel, F. Fontaine, N. Vaillant-Gaveau, and C. Clement. 2008. Sugars and flowering in the grapevine (Vitis vinifera L.). J. Expt. Bot. 1:1-14.

Percival, D.C., K.H. Fisher, and J.A. Sullivan 1994. Use of fruit zone leaf removal with Vitis vinifera $\mathrm{L}$. cv. Riesling grapevines. II. Effect on fruit composition, yield, and occurrence of bunch rot. Amer. J. Enol. Viticult. 45:133-139.

Petrie, P.R., M.C.T. Trought, G.S. Howell, and G.D. Buchan. 2003. The effect of leaf removal and canopy height on whole-vine gas exchange and fruit development of Vitis vinifera L. Sauvignon blanc. Func. Plant Biol. 30:711-717.

Poni, S., F. Bernizzoni, G. Briola, and A. Cenni. 2005. Effects of early leaf removal on cluster morphology, shoot efficiency and grape quality of two Vitis vinifera cultivars. Acta Hort. 689: 217-225.

Poni, S., F. Bernizzoni, S. Ciavardi, and N. Libellini. 2009. Effects of pre-bloom leaf removal of berry tissue and must composition in two red Vitis vinifera L., cultivars. Aust. J. Grape Wine Res. 15:185-193.

Poni, S., L. Casalini, F. Bernizzoni, S. Civardi, and C. Intrieri. 2006. Effects of early defoliation on shoot photosynthesis, yield components, and grape composition. Amer. J. Enol. Viticult. 57: 397-407.

Pool, R.M. and G.E. Howard. 1984. Managing vineyards to survive low temperatures with some potential varieties for hardiness. Proc. International Symp. Cool Climate Viticulture and Enology. Oregon State Univ. p. 184-197.

Price, S.F., P.J. Breen, M. Valladao, and B.T. Watson. 1995. Cluster sun exposure and quercetin in Pinot noir grapes and wine. Amer. J. Enol. Viticult. 46:187-194.

Reynolds, A.G., R.M. Pool, and L.R. Mattick. 1986. Influence of cluster exposure on fruit composition and wine quality of Seyval blanc grapes. Vitis 25:85-96.

Reynolds, A.G., D.A. Wardle, and A.P. Naylor. 1996. Impact of training system, vine spacing, and basal leaf removal on Riesling. Vine performance, berry composition, canopy microclimate, and vineyard labor requirements. Amer. J. Enol. Viticult. 47:63-76.

Sabbatini, P., G.S. Howell, and J.A. Wolpert. 2010. Impatto della defogliazione precoce su crescita produzione, qualita' e marciumi del grappolo alla raccolta. Italus Hortus 17:27-32.

Smart, R.E., J.K. Dick, I.M. Gravett, and B.M Fisher. 1990. Canopy management to improve grape and yield and wine quality-Principles and practices. S. Afr. J. Enol. Viticult. 11:3-17.

Tardaguila, J., F.M. de Toda, S. Poni, and M.P. Diago. 2010. Impact of early leaf removal on yield and fruit and wine composition of Vitis vinifera L. Graciano and Carignan. Amer. J. Enol. Vitic. 61:372-381.

U.S. Department of Agriculture, Soil Conservation Service. 1957. Major soils of the north central region, USA map. Soil survey, North Central Regional Publication 76. Government Printing Office, Washington, DC

Vasconcelos, M.C., M. Greven, C.S. Winefield, M.C.T. Trought, and V. Raw. 2009. The flowering process of Vitis vinifera: A review. Amer. J. Enol. Viticult. 60:411-433.

Zoecklein, P.W., T.K. Wolf, N.W. Duncan, J.M. Judge, and M.K. Cook. 1992. Effects of fruit zone leaf removal on yield, fruit composition, and fruit rot incidence of Chardonnay and White Riesling (Vitis vinifera L.) grapes. Amer. J. Enol. Viticult. 43:139-148. 